\title{
1. An introduction to critical studies of think tanks
}

\section{Julien Landry}

Think tanks have become enduring fixtures of national and transnational political landscapes. Their numbers are not easily tallied since they are difficult to define and sometimes quick to form and dissolve, but by one estimate there are over 8000 of them worldwide (McGann 2019). Early examples of think tanks, or think tank-like organizations, date back to the nineteenth century, including in the United States and the United Kingdom (Denham and Garnett 1998; Smith 1991; Stone 1996). Many of them also trace their origins to the post-war era. However, many countries only began exhibiting recognizable think tank landscapes in the last decades of the twentieth century. In fact, the proliferation of these organizations accelerated everywhere during this period; and the number of American think tanks more than doubled after 1980. The rate of creation of new think tanks has since waned in North America and Europe, but they are on the rise in developing countries, while Asia has seen a veritable explosion of think tanks in the last 20 years (McGann 2019).

These organizations are also subject to increased scholarly attention. Think tanks are in the business of producing and circulating ideas, knowledge and expert discourse on matters of public and private import (from economic, social, environmental and foreign policy to democratic reform, public administration and business intelligence). As objects of study, they can be scrutinized to understand how social forces organize knowledge production about social systems and their environments. They also open a window into the changing role and status of expert discourse in modern societies. However, they often generate interest because they are objects of considerable ambivalence. Their proliferation is associated with the advent of more fraught policy environments, contradictory messaging, uncertainty regarding expertise and an overt melding of research, advocacy and political mobilization. Although they are frequently painted as sources of dispassionate advice and expertise - or at the very least informed advocacy - they also inspire resentment and suspicion from political adversaries and academics alike. The latter feel particularly threatened by the possibility of being displaced in their role as producers of public wisdom by policy experts who are not as beholden to their preference 
for autonomous analysis and advice (see Medvetz 2012b; Misztal 2012). Think tanks are not all equally geared towards ideological advocacy, but even technocratic and scholarly think tanks are invested in structures of power that both enable the mobilization of knowledge for decision-making and limit the horizon of admissible policy objectives.

The aim of this volume is to develop the study of think tanks from a critical perspective, while supplying a point of reference for this scholarship. Broadly critical research on think tanks has seen a resurgence in recent years (for example, Carroll 2013; Gonzalez Hernando 2019; Medvetz 2012b; Pautz 2012; Plehwe 2014; Ruser 2018; Salas-Porras and Murray 2017), but there is a need to construct a more synthetic point of departure for understanding these approaches. This volume aims to provide this reference. The chapters herein discuss multiple countries (including Brazil, Canada, Germany, Mexico, and the United States) and two transnational jurisdictions: the Association of Southeast Asian Nations (ASEAN) and the European Union (EU). They also cover several intersecting themes: evolving modalities of intellectual and expert interventions; political and social dynamics of brokering knowledge and marketing ideas; the mutual structuring of discourse, power and influence; and the role of think tanks in systems of knowledge production. More broadly, these chapters collectively engage in fostering critical discussion on the interplay between knowledge, politics and power and the role of think tanks in these dynamics.

Think tanks are both incredibly diverse and difficult to define. They are in part recognized by a mix of activities geared towards the production and circulation of policy research, political talent and ideas. Think tank staff along with other contributors conduct research and policy analysis, disseminate commentaries and ideas through the media and Internet, carry out contractual research projects and policy evaluations, intervene in various government committees and commissions, and organize various events to reach their constituencies, generate revenue and hold policy discussions. However, think tanks vary in their propension to engage in these activities, all the while sharing characteristics with other bodies like advocacy organizations, speakers' clubs, consultancies, sectorial associations, business and labour bureaus and university research centres.

This also begs the question of what exactly the impact of think tanks is. Unfortunately, there is no simple answer. Policy networks and policy subsectors, for starters, vary in their permeability to organized interests and in their reliance on policy expertise (Atkinson and Coleman 1992). Likewise, some countries and political institutions are more amiable to the organization of multiple locales of policy research and expert advice (Campbell and Pedersen 2011, 2014). Think tank managers make use of anecdotes and indicators to bolster their claim to influence and attract talent and donors, but they 
themselves easily recognize (typically in private) that political influence is an intangible force and that ideas permeate the policy process through many channels (Abelson 2018). In fact, it is not always clear exactly who is exerting an influence when think tanks act. Not only are these organizations funded and supported by distinct social forces with unequal resources (like state institutions, foundations, corporate interests, political parties, labour unions and other political actors), they also form forums of expression for distinct communities of discourse producers that may or may not be employed by the think tanks per se (Landry 2020).

Yet this doesn't mean that the influence of think tanks is only diffused and indirect. By integrating specific networks and communities of political discourse, think tanks are organized around different degrees of proximity to states, legislatures, universities and stakeholders, and thus find various ways to plug into the policy process. Depending on the niches they occupy, think tanks engage in 'coordinative discourse' between 'the individuals and groups at the centre of policy construction' in the 'policy sphere,' and/or in 'communicative discourse' as organizations 'involved in the presentation, deliberation, and legitimation' of policy ideas 'in the political sphere' (Schmidt 2008, p. 310). Think tanks are not alone in incorporating these niches and must navigate crowded landscapes of so-called 'knowledge brokers' even as some think tanks integrate more privileged policy networks (Stone 2007). However, think tanks can also shape the arena of policymaking itself by contributing to its rules, dynamics and institutional barriers (Medvetz 2015) or by redrawing the terrain of recognizable political adversaries (Cahill 2010). By shifting the composition of expressed political and public opinions, think tanks can reorder dominant conceptions of what counts as political moderation (Gonzalez Hernando 2019; Stahl 2016) and alter the background conditions of political bargaining (Salas-Porras and Murray 2017).

This volume explores the role of think tanks in these variegated arenas of policy discourse and influence from the perspective of critical policy studies. This introduction will illustrate: (1) how the contributions to this volume fit within the umbrella of critical policy scholarship; (2) how they deal with the slippery concept of think tanks; and (3) how they can inform our understanding of the ways that think tanks integrate institutional environments and influence both political and policy processes.

\subsection{WHAT IS CRITICAL SCHOLARSHIP ON THINK TANKS?}

Critical policy studies examine policy processes and policy analytical practices while underscoring the way 'interests, values and normative assumptions' shape these processes and practices (Fischer et al. 2015, p. 1). Having 
emerged from various strands of mid-twentieth-century scholarship sceptical of positivism and techno-scientific approaches to social science and policy, critical policy studies came out of opportunities to challenge the technocratic ethos of the post-war era that was being put to the test by various social movements, economic and environmental crises and political and existential anxieties worldwide. It also took shape in the wake of older critical research. By highlighting the intersection of facts and values and knowledge and power, early critical scholarship - some of it inspired by various strands of Marxism - spread throughout academia in the post-war era to renew classical matrices of social enquiry dealing with domination, institutional oppression and conditions of emancipation. Some of these enquiries also encapsulated new topics for highlighting structural adversities and power relations such as race, gender and colonial relationships.

In the 1980s and 1990s, critical policy studies came of age as earlier critics of scientism (like Jürgen Habermas) and knowledge production (like Michel Foucault) provided inspiration for questioning the assumptions, power relations and communication practices that structure policy processes and political decisions (see Lövbrand and Stripple 2015; Saretzki 2015). These strands of research also pay respects to Harold D. Laswell's 'policy sciences' orientation by emphasizing this founder of policy analysis's defence of multidisciplinary research, contextualization and moral engagement; all the while criticizing some of the positivist tensions in his work (see Torgerson 2007, 2015). From the 1980s onwards, policy analysis in general increasingly criticized technocratic orientations and examined the role of values, ideas, stakeholders and debates in policy processes (see Enserink et al. 2013; Goodin et al. 2006). Meanwhile, networks of more critical scholars developed concepts to underline the value-laden and argumentative character of these processes, partly in order to show how they can limit the range of imaginable and acceptable policy solutions (see Fischer and Forester 1993; Fischer and Gottweis 2012). These strands of scholarship now comprise multiple research programmes privileging the study of discourse and the political dimensions of expertise, while sometimes advocating for deliberative and participatory models of policy development (Fischer et al. 2015, p. 5). They are also often informed by scholarship that highlights dominant assumptions and rules of discussion (Hall 1993) or the institutional structures (Campbell and Pedersen 2011) that govern the competition between holders of distinct narratives (Hajer 1993). These rules, institutions and struggles are often fraught with gate-keeping practices, powerful interests and mechanisms of exclusion.

Critical policy studies can therefore be framed as a commitment to challenge relations of power and to foster democratic practices and alternative policy orientations. However, in order to temper the tendency for competing research programmes to drift towards needless factionalism, it is useful to frame critical 
policy studies as an analytical stance, whose capacity to enable alternative political avenues is an essential but separate feature. This scholarship can thus be said to, foremost, feature commitments to highlight: (1) the role of power and interests in limiting the range of policy choices and shaping the development of policy; (2) the social underpinnings of expert discourse and expertise that enable the intersection of knowledge, interests, values and power in adversarial and coordinative political arcades; and (3) the impossibility of a neutral position in policymaking and the centrality of necessarily normative, political or adversarial elements in policy processes. Although critical policy scholars combine these concerns in specific ways, they share some of these components with a wider range of scholarship and can trade insights more broadly. The study of think tanks provides a compelling point of departure for critical policy scholars invested in examining these dimensions.

(1) The role of power and interests. Theoretical frameworks that directly engage with power and the unequal distribution of access and resources have led critical think tank studies to draw attention to the ways that knowledge and discourse on policy flow through and from various social forces and centres of power. Early critical studies of think tanks - and of policy planning organizations more broadly - attached considerable import to the role of elite networks in monopolizing policy capacity for elite coordination and consensus formation (Domhoff 1975; Domhoff and Dye 1987; Dye 1978), while other elite theorists emphasized the role of these organizations in restructuring the convictions of elites during America's rightward turn in the 1980s (Peschek 1987; Saloma 1984). These studies provided enduring insights into the interconnections that structure the networks in which insular policy elites operate. However, recent critical scholarship increasingly avoids the idea of a single coordinated elite and engages with alternative frameworks for relaying both multiple sites of power and endemic struggles over values and ideas (Fischer 1993; Salas-Porras and Murray 2017). Among other inspirations, critical studies of think tanks have borrowed from: neo-Gramscian perspectives on cultural hegemony and counter-hegemonic struggles (Carroll 2013, 2014; Carroll and Sapinski 2010; Carroll and Shaw 2001; Desai 1994; Pautz 2011; Peetz 2017); Bourdieusian models of field relations (Landry 2020; McLevey 2015; Medvetz 2012a, 2012b, 2015; Salas-Porras 2018); Hajer's discourse coalition framework (Pautz 2012; Plehwe 2015); discursive institutionalism (Ladi 2011; Ladi et al. 2018); and the knowledge regime framework (Campbell and Pedersen 2011, 2014; Nachiappan 2013; Ruser 2018). These approaches serve to articulate: (1) the intersecting relationships between power, policy, politics and knowledge; (2) the social and institutional topography of actors and interests involved in coordinative, communicative or antagonistic dynamics; and (3) the way policy orientations can be affected by control over infrastructures of knowledge production and dissemination. 
(2) The social underpinnings of expert discourse. Engagement with the idea that knowledge is socially constructed, has allowed critical think tank studies to draw inspirations from the sociology of knowledge. One important source of inspiration has been studies of the production and circulation of both ideas and knowledge producers in the interstices between institutional fields (for example, Eyal 2002, 2006, 2013; Stampnitzky 2011, 2013). Whereas the classical sociology of intellectuals sought to characterize the allegiance (or lack thereof) of discourse producers to political and economic forces (Kurzman and Owens 2002), a new focus on the sociology of intellectual interventions (Eyal and Buchholz 2010) has recast problematic essentializations of the quintessential public intellectual in order to study the myriad of actors involved in intellectual work (Jacobs and Townsley 2011) and their various modes of intervention and association (Sapiro 2009). Thomas Medvetz (2010, 2012a, $2012 \mathrm{~b}, 2015$ ) then applied this orientation to think tanks by using Bourdieusian concepts (Bourdieu and Wacquant 2013) to theorize the space of American think tanks as an interstitial field drawing practices and resources from more established fields. By underscoring the 'hyper-dependence' of think tanks to multiple logics of action and social forces (Medvetz 2013, p. 575), this model explains how relative proximities (in terms of structural ties and affinities) to academic, political, economic and media actors and the state modulate the strategic behaviour of think tanks and their modes of intellectual intervention (Gonzalez Hernando 2019; Landry 2020; McLevey 2015; Medvetz 2012b). It also helps illustrate how think tanks enable the formation of discourse coalitions comprising elites from multiple institutional fields (Salas-Porras 2018).

(3) The impossibility of a neutral position. The commitment to break with the illusion of 'post-political' policymaking (Mouffe 2005) has allowed critical studies of think tanks to engage with the assumptions, interests and values that think tanks bring into the forums and battlegrounds of politics and public policy. In policy studies in general, concepts such as 'epistemic communities' (Haas 1992) and 'advocacy coalitions' (Sabatier 1987) underscore the cognitive parameters and adversarial engagements of policy networks and the exclusions and hierarchies these can entail for think tanks therein (Stone 1996; Stone and Denham 2004; Stone et al. 1998). However, increased attention to multifaceted narratives and argumentation strategies (Fischer 2003; Hajer 1993), normative aspects of policy discourse (Campbell 1998) and modes of discourse mobilization (Carstensen and Schmidt 2016; Schmidt 2008) - among other considerations like a renewed interest in the struggles over cultural hegemony (Carroll and Shaw 2001; Desai 1994; Pautz 2011) - have enabled critical scholars to underline how think tanks can promote normative convictions, challenge autonomous research and displace or limit the range of acceptable policy styles and options by integrating resource-rich networks composed of actors whose assumptions and interests align with the ideas of 
think tanks (Carroll 2013; Jacques et al. 2008; Lepont 2016; McKewon 2012; Medvetz 2015; Pautz 2018; Plehwe 2014; Plehwe et al. 2018; Ruser 2018; Salas-Porras 2018).

To summarize, critical think tank studies look at these organizations while addressing unchallenged expressions of power, the social construction of knowledge and the role of assumptions, interests and values in political and policy processes. The contributions to this volume thus provide insight into the various ways that power, including material and symbolic resources, distorts the fabric of policy arenas and the limits of what is likely (or even possible) therein.

The first part of this volume provides examples of how the interplay between intellectual work and forms of power has evolved. Guillaume Lamy (Chapter 2) recounts the history of intellectual forces (including mendicant orders, early political parties, public intellectuals and now advocacy tanks) to show how they adapt to the resources and legislative arrangements of political ecosystems and competition therein. Matthias Kipping (Chapter 3) provides an account of how think tanks and consultancies converged at various junctures throughout the twentieth century and arrives at important insights into the possible motivations of actors shaping the production and commodification of expert advice in recent years.

The second part of this volume illustrates how think tanks can disseminate knowledge and establish connections with various elites in ways that mediate forms of social power or accommodate political forces. Alejandra Salas-Porras (Chapter 4) lays out the various ways that independent Mexican think tanks (of right-wing, technocratic and social liberal persuasions) intervene in public debates, and she questions whether the power relations that enable these engagements can truly generate a more democratic public sphere. Thomas Alam (Chapter 5) reports on ethnographic fieldwork at Epode European Network and describes the topography of actors involved in this food-industry-backed think tank's efforts to promote solutions to the global obesity epidemic that avoid the imposition of levies and regulations on unhealthy foods. Donald E. Abelson (Chapter 6) documents the relationships between think tanks and the last three American presidents (including Donald Trump's indifference towards expertise) and illustrates by example how more canonical political analysis can contribute to critical scholarship when it engages on issues of fraught credibility and conditional access.

The third part of this volume explores some of the political and policy shifts engendered or facilitated by the social and ideational power of think tanks. Dieter Plehwe (Chapter 7) provides new insights into the role of think tanks in the history of entrepreneurial discourse and asks if neoliberal think tanks have contributed to the pervasiveness of corporate power by renewing academic and ideological discourse on entrepreneurialism. Juliana Hauck and Ciro Resende 
(Chapter 8) track the contribution of business-backed pro-market think tanks to the ascent of the right-wing forces led by Jair Bolsonaro in Brazil. Erin Zimmerman (Chapter 9) illustrates how ideational actors like think tanks were deeply involved in the coordinative and communicative practices that overcame institutional resistance and reshaped governance discourse on human rights in the ASEAN region.

The fourth and final part of this volume applies a critical lens to how the social forces that support think tanks can craft spheres of truth that shape social systems of knowledge production and complicate attempts to assess their epistemic contribution. Julien Landry (Chapter 10) compares the history of think tanks and expert discourse in Canada and the United States to suggest that advocacy tanks may have paved the way to the so-called 'post-truth era.' Alexander Ruser (Chapter 11) challenges the idea that think tanks can be conceived as relays of knowledge by examining their roles in widening the gap between scientific and everyday understandings of climate change in the United States. Andréanne Veillette, François Claveau and Amandine Catala (Chapter 12) conclude the volume with a demonstration of how critical scholarship can contribute to a social-epistemic evaluation of the knowledge produced by think tanks; notably in terms of epistemic justice.

\subsection{WHAT ARE THINK TANKS AND WHY SHOULD THEY BE STUDIED?}

Contributions to this volume examine different types of organizations that fall within the ambit of think tanks, but these actors are also difficult to define. Think tanks are not alone in attempting to mobilize knowledge to shape the policy agenda or the limits of politically acceptable endeavours. It is also difficult to establish clear distinctions between them and other policy actors like consultancies, university research centres and research-intensive advocacy organizations, especially since think tanks themselves are variform and diverse.

American think tanks were, for a time, recognized as belonging to a specific organizational form - that is, as 'independent, non-interest-based, non-profit organizations that produce and principally rely on expertise and ideas to obtain support and to influence the policymaking process' (Rich 2004, p. 11). However, studies comparing the make-up of policy research organizations in different contexts (Stone and Denham 2004; Stone et al. 1998) suggest that this definition has a limited reach. Think tanks in other jurisdictions - like Germany and China - are often not independent from political parties or the state and, even in America, they have been known to be embedded in universities or intimate with parties or politicians (Abelson 2006). Early typologies distinguishing scholarly, contract-based and advocacy tanks (Weaver 1989) 
have evolved to include more diverse types of think tanks that can be 'autonomous and independent,' 'quasi independent,' 'government affiliated,' 'quasi governmental,' 'university affiliated,' 'political party affiliated' or 'for profit' (McGann 2019, p. 13). These typologies offer some insight into the elasticity of the think tank category, but they do little to assuage their indistinction from other policy actors. Independence is also a misleading label for organizations that hardly exhibit actual autonomy from the resources of various social forces and interests (Drezner 2017; Medvetz 2012b, 2013).

Attempts to define think tanks as if they were a natural type are necessarily arbitrary if not normative. Defining what a true think tank is, is itself a stake in the struggle to define legitimate public interventions (Medvetz 2012b). The think tank label is an identity and a folk category whose meanings are ultimately variform and social. Nonetheless, it is an identity that has taken shape in specific historical circumstances according to particular social relations. This is why James McGann - the guru of a popular think tank hit parade - can define think tanks as 'public-policy research, analysis and engagement organizations that generate policy-oriented research, analysis, and advice on domestic and international issues' and 'often act as a bridge between the academic and policymaking communities and between states and civil society' (McGann 2019 , p. 12). In other words, think tanks are at least relatively specific in the parameters of their diversity. This definition covers multiple organizations that gravitate in various ways towards policy discussions, knowledge production, political advocacy, discourse dissemination, policy advice and information services.

One distinctive feature is the hybrid nature of think tanks. Think tanks have long been analysed as negotiating rival tensions between the exigencies of social science research and the desire to secure funding, visibility, influence, access and allies (Abelson 2018; Rich 2004; Stone 1996). Likewise, according to Medvetz (2012b), they embody a dynamic balancing act between the goals, resources, temporalities and logics of multiple fields (academia, media, civil service, politics and business). This liminal position thus involves catering to competing desiderata (academic credibility, media savviness, policy relevance, political timing and resonance, business acumen and economic importance), all the while facilitating the circulation of people, resources and ideas between these fields. One could argue that the fuzziness of the boundaries between think tanks and other organizations is an inalienable feature, such that other organizations can be excluded from the category by being more completely absorbed into the singular logic of a neighbouring field, like university research centres (university field), political or sectoral advocacy bodies (political field), government research units (bureaucratic field), consulting firms (economic field) and news organizations that publish columns on public policy 
(media field). ${ }^{1}$ This means that the very distinctiveness of think tanks can be a fragile thing both for individual organizations and for think tanks in general.

Some of the authors in this volume address how the hybrid nature of think tanks impacts the negotiation of exactly what a think tank is. Kipping (Chapter 3) tracks how consultation firms have always straddled the world of think tanks by serving both economic and policy clients and are now spawning affiliated think tanks of their own. Likewise, the contributions of Lamy (Chapter 2), Abelson (Chapter 6), Landry (Chapter 10) and Ruser (Chapter 11) collectively suggest that the roles of advocacy tanks are increasingly becoming functionally equivalent to modalities of political action that are not inherently based on research or expertise.

In the end, it is because, not despite, of their ambiguity that think tanks provide a compelling point of departure from which to explore the intersecting relationships between power, policy, politics and knowledge. For example, Zimmerman (Chapter 9) contrasts the forms of power used by conventional political actors and those mobilized by ideational actors like think tanks, while Lamy (Chapter 2) draws a parallel between them by underlining their shared use of logistical capabilities to shape public opinion and social life. The hybrid nature of think tanks allows these two perspectives to be both in tension and correct at the same time. Here, the question is not whether think tanks inhabit the world of ideas or the world of politics, but whether they sustain the distinction between these worlds even as they straddle them both (see Medvetz 2015).

By focusing on how think tanks exhibit different properties depending on how they span the networks and institutions of more established social actors like political parties, media outlets, economic interests and the state, the contributions to this volume illustrate how intellectual commitments and political or economic interests are dialectically intertwined. Salas-Porras (Chapter 4), Alam (Chapter 5), Plehwe (Chapter 7) and Hauck and Resende (Chapter 8) provide accounts of how the production and circulation of corporate-friendly ideas are tied to concrete alliances between certain think tanks, business interests and the political commitments of both conservative and neoliberal advocates. Where each of these camps have their own interests and commitments at heart, none can be painted as exclusively servile to either interests or ideas. Nonetheless, the contributions in this volume offer concrete insights into how asymmetric social forces support distinct communities of discourse that enter-

$1 \quad$ For example, some university-based research institutes become identifiable as think tanks by producing policy reports or public interventions, but others are more clearly aligned with traditional academic functions such as teaching and scholarly publication (see Abelson 2016, 2018). Likewise, unlike conventional interest groups, think tanks do not typically organize protests, represent specific groups or make political donations (Abelson 2018; Peetz 2017). 
tain various degrees of homophily; as exemplified not just by militant think tanks, but also by networks of consultants and technocrats that straddle think tanks and state institutions (see Ruser 2018). In the aggregate, as Veillette, Claveau and Catala (Chapter 12) argue, these forums of networking and intellectual expression integrate ecosystems comprised of various producers, receivers and channels of communication. However, they also vary in relation to the opportunities provided by different institutional contexts.

\subsection{PLUGGING INTO NATIONAL AND TRANSNATIONAL CIRCUITRIES OF KNOWLEDGE AND POWER}

Through their hybridity and diversity, think tanks invite us to think geographically about the policy process. As outlined above, recent scholarship has emphasized the grounding of think tanks in interstitial social positions that straddle the worlds of politics, policymaking, academic research, media commentary and economic interests (Eyal 2002; Medvetz 2012b). These positions and the relative importance of politics, academics and outreach in a think tank's repertoire have been shown to structure how these organizations legitimize their intellectual products (McLevey 2015) and establish lasting relationships that structure their involvement with policy networks (Landry 2020). The literature on think tanks also underscores these ties by analysing the 'niches' (Abelson 2016) 'constituencies' (Plehwe 2014) or 'webs of influence' (Plehwe 2015) that think tanks occupy in order to form, endure and produce meaningful interventions.

Some of these networks and communities are transnational in scope, relaying the growing diversity of sites that think tanks have incorporated to mediate the flow of ideas (Carroll 2014; Carroll and Carson 2003; McGann 2002; Stone 2004, 2013; Zimmerman and Stone 2018). For example, Zimmerman (Chapter 9) illustrates how the knowledge and expert discourse mobilized by think tanks can generate considerable influence in transnational arcades like ASEAN where more conventional governance structures are weak or underdeveloped, while Alam (Chapter 5) examines the circuitry that allows think tanks to amplify industrial interests through the interplay between scientific credentials and the governing institutions of the EU.

National contexts also feature different think tank landscapes. The state-dominated policy advisory traditions of continental Europe and more market-based Anglo-Saxon models differ considerably even as the proliferation of think tanks and other externalizing forces relativize the differences between these models (Kelstrup 2016). Moreover, Anglo-Saxon countries themselves differ in how they enable the proliferation of think tanks (compare Abelson 2018; Baier and Bakvis 2010; Denham and Garnett 1998; Hart and 
Vromen 2008; Lindquist 2004). In the United States, in particular, think tanks maintain a dynamic interpenetration of partisan intellectuals and bureaucratic and academic actors in ways that think tanks in Westminster-style democracies could only dream of reproducing (Abelson 2018; Weiss 1992).

These observations underline the significance of the 'knowledge regime' in which policy organizations operate (Campbell and Pedersen 2011, 2014). The main parameters of knowledge regime variation are the gradations of private or state control over market relations and the degrees to which policy advisory systems are centralized. As such, it is the relative importance of economic forces, partisan politics, state power and academic capacity in organizing policy analytical capacity that governs the composition and internal dynamics of a knowledge regime - that is to say, the prevalence of 'scholarly,' 'advocacy,' 'party' and 'state' 'research units' (Campbell and Pedersen 2011, pp. 171-2). As Campbell and Pedersen (2011, 2014) argue, the institutional configuration of economic and political forces helps explain why the American knowledge regime (with its liberal economy and decentralized political structure) is fraught with highly partisan and antagonistic dynamics of knowledge production. As made clear by Abelson's contribution (Chapter 6), these dynamics can, under extreme conditions, challenge the relevance of the policy expertise of think tanks themselves. They can also, as Ruser reasons (Chapter 11), impel think tanks to move away from the repertoire of expertise altogether to challenge scientific cannon. As Landry recounts (Chapter 10), other knowledge regimes, like Canada's, are not as subsumed by such dynamics especially if they prioritize state capacity (see also Ruser 2018).

These observations also have historical significance. As Lamy puts it (Chapter 2), think tanks and other types of political intellectuals proliferate thanks to the resources that are made available to them in response to new material developments, competitive pressures and legislative arrangements. Accordingly, Kipping (Chapter 3) illustrates how consultancies changed throughout the twentieth century in part in response to competitive pressures exerted by firms developing new ways to meet the evolving demand for knowledge and ideas.

In other words, institutional environments and political economies shape competitive dynamics and provide unequal resources and access to different types of think tanks and knowledge actors. It is this interlay of predominant social forces that explains why the increasingly diverse means of public policy engagement in Mexico described by Salas-Porras (Chapter 4) and the rise of a conservative discourse coalition in Brazil outlined by Hauck and Resende (Chapter 8) are ultimately attributable to mobilizations of material and symbolic resources (such as money, access, instruments of knowledge and credibility) that can constrain political choice in so much as they are translating unequal distributions of power into unequal capacities to support ideas. 
Another example of how social forces shape infrastructures of knowledge production is the People's Republic of China, where dominant 'official' and 'semi-official' think tanks enjoy 'fortified' access to Beijing, while 'private think tanks' are buttressed by 'universities, overseas foundations, private enterprises and other sectoral partners' and emerged more recently 'as a direct consequence of the marketization of the Chinese economy' (Nachiappan 2013, pp. 260-2).

This relationship between the organization/distribution of social forces and the presence and activities of think tanks explains, as Plehwe argues (Chapter 7), why the rise or resurgence of certain discourses at the hands of think tanks can fuel the pervasiveness of dominant social forces as in the case of entrepreneurship discourse and corporate power. This is not to say that learning cannot occur within a given set of power arrangements. As Zimmerman makes clear (Chapter 9), the think tanks who helped institutionalize human rights discourse in ASEAN were far from outsiders to the institutional structures of Southeast Asia. However, as in the case of Epode European Network examined by Alam (Chapter 5), policy learning can be heavily oriented by the forces that govern the circuity of knowledge production in a given knowledge/policy interface. Accordingly, and as demonstrated by Veillette, Claveau and Catala (Chapter 12), it is at the level of these broader flows of power, resources and knowledge - the ecosystemic level - that critical scholarship can most meaningfully evaluate the ways that societies organize their knowledge production.

\subsection{CONCLUSION: REITERATING AN OLD IDEA}

As argued above, the ways that think tanks plug into societies are structured by how policy units are organized in a given policy advisory system or knowledge regime. This indicates how think tanks are not so much 'bridges' between knowledge and politics but 'a manifestation of the knowledge/power nexus' (Stone 2007, p. 276) as it presents itself in various national and transnational arcades. However, because they integrate different niches, think tanks also play this role in different ways. From context to context, this translates into dissimilar levels of think tank engagement with various stages or aspects of the policy process (Abelson 2018; Landry 2021; Rich 2004). It also actualizes the 'different paths' to influence in which different think tanks often specialize, including the persuasion of policymakers, the reordering of public opinion and the construction of elite policy communities (Salas-Porras and Murray 2017, p. 19).

Knowledge regimes - or more precisely the organization of state resources and private interests that these suppose - thus govern the supply and demand for policy ideas. Accordingly, they help explain the allocation of material and symbolic resources to knowledge producers that end up playing different roles 
and serving distinct interests. Contributions to this volume have highlighted how the dynamics of this supply and demand vary both historically and geographically. They also illustrate how the unequal distribution of social power translates into an unequal distribution of ideational power. However, since power is multifaceted and diverse, discursive shifts that challenge dominant power relations and foster enlightened publics and democratic inclusion are possible. Power may drive the framing, and even the outcomes of policy debates, but knowledge production and politics have lives of their own and involve actors who rely on various forms of power, credibility and legitimacy. It is perhaps not insignificant that critical scholarship is rediscovering an old idea that state or civil action to change how power is distributed, or at the very lease manifested, could be necessary if societies are to transform how they are collectively understood through knowledge and learning. Further analysis of these realities could contribute to ongoing work on institutional levers and democratic reforms aimed at meaningful change in how knowledge and ideas are produced, communicated and even shared by policy experts and stakeholders.

\section{REFERENCES}

Abelson, D.E. (2006), A Capitol Idea: Think Tanks and US Foreign Policy, Montreal: McGill-Queen's University Press.

Abelson, D.E. (2016), Northern Lights: Exploring Canada's Think Tank Landscape, Montreal: McGill-Queen's University Press.

Abelson, D.E. (2018), Do Think Tanks Matter?: Assessing the Impact of Public Policy Institutes, 3rd edn, Montreal; Kingston: McGill-Queen's University Press.

Atkinson, M.M. and W.D. Coleman (1992), 'Policy networks, policy communities and the problems of governance', Governance, 5 (2), 154-80.

Baier, G. and H. Bakvis (2010), 'Think tanks and political parties in Canada: competitors or collaborators?', in A. Garcé and G. Uña (eds), Think Tanks and Public Policies in Latin America, Buenos Aires: Fundación Siena; CIPPEC, pp. 34-45.

Bourdieu, P. and L.J.D. Wacquant (2013), An Invitation to Reflexive Sociology, Cambridge; Malden, MA: Polity Press.

Cahill, D. (2010), 'Business mobilisation, the New Right and Australian Labor governments in the 1980s', Labour History: A Journal of Labour and Social History, 98, 7-24.

Campbell, J.L. (1998), 'Institutional analysis and the role of ideas in political economy', Theory and Society, 27 (3), 377-409.

Campbell, J.L. and O.K. Pedersen (2011), 'Knowledge regimes and comparative political economy', in D. Béland and R.H. Cox (eds), Ideas and Politics in Social Science Research, New York: Oxford University Press, pp. 167-90.

Campbell, J.L. and O.K. Pedersen (2014), The National Origins of Policy Ideas: Knowledge Regimes in the United States, France, Germany, and Denmark, Princeton, NJ: Princeton University Press.

Carroll, W.K. (2013), 'Networks of cognitive praxis: transnational class formation from below?', Globalizations, 10 (5), 691-710. 
Carroll, W.K. (2014), 'Alternative policy groups and transnational counter-hegemonic struggle', in Y. Atasoy (ed.), Global Economic Crisis and the Politics of Diversity, Basingstoke: Palgrave Macmillan, pp. 259-84.

Carroll, W.K. and C. Carson (2003), 'The network of global corporations and elite policy groups: a structure for transnational capitalist class formation?', Global Networks, 3 (1), 29-57.

Carroll, W.K. and J.P. Sapinski (2010), 'The global corporate elite and the transnational policy-planning network, 1996-2006: a structural analysis', International Sociology, 25 (4), 501-38.

Carroll, W.K. and M. Shaw (2001), 'Consolidating a neoliberal policy bloc in Canada, 1976 to 1996', Canadian Public Policy/Analyse de Politiques, 27 (2), 195-217.

Carstensen, M.B. and V.A. Schmidt (2016), 'Power through, over and in ideas: conceptualizing ideational power in discursive institutionalism', Journal of European Public Policy, 23 (3), 318-37.

Denham, A. and M. Garnett (1998), British Think-Tanks and the Climate of Opinion, London; Bristol, PA: UCL Press.

Desai, R. (1994), 'Second-hand dealers in ideas: think-tanks and Thatcherite hegemony', New Left Review, 203, 27-64.

Domhoff, G.W. (1975), 'Social clubs, policy-planning groups, and corporations: a network study of ruling-class cohesiveness', Critical Sociology, 5 (3), 171-84.

Domhoff, G.W. and T.R. Dye (eds) (1987), Power Elites and Organizations, Newbury Park, CA: Sage Publications.

Drezner, D.W. (2017), The Ideas Industry, New York: Oxford University Press.

Dye, T.R. (1978), 'Oligarchic tendencies in national policy-making: the role of the private policy-planning organizations', The Journal of Politics, 40 (2), 309-31.

Enserink, B., J.F.M. Koppenjan and I.S. Mayer (2013), 'A policy sciences view on policy analysis', in W.A.H. Thissen and W.E. Walker (eds), Public Policy Analysis New Developments, New York: Springer, pp. 11-40.

Eyal, G. (2002), 'Dangerous liaisons between military intelligence and Middle Eastern studies in Israel', Theory and Society, 31 (5), 653-93.

Eyal, G. (2006), The Disenchantment of the Orient: Expertise in Arab Affairs and the Israeli State, Stanford, CA: Stanford University Press.

Eyal, G. (2013), 'Spaces between fields', in P.S. Gorski (ed.), Bourdieu and Historical Analysis, Durham, NC: Duke University Press, pp. 158-82.

Eyal, G. and L. Buchholz (2010), 'From the sociology of intellectuals to the sociology of interventions', Annual Review of Sociology, 36 (1), 117-37.

Fischer, F. (1993), 'Policy discourse and the politics of Washington think tanks', in F. Fischer and J. Forester (eds), The Argumentative Turn in Policy Analysis and Planning, Durham, NC: Duke University Press, pp. 21-42.

Fischer, F. (2003), Reframing Public Policy Discursive Politics and Deliberative Practices, Oxford; New York: Oxford University Press.

Fischer, F. and J. Forester (eds) (1993), The Argumentative Turn in Policy Analysis and Planning, Durham, NC: Duke University Press.

Fischer, F. and H. Gottweis (2012), 'Introduction: the argumentative turn revisited', in F. Fischer and H. Gottweis (eds), The Argumentative Turn Revisited: Public Policy as Communicative Practice, Durham, NC: Duke University Press, pp. 1-27.

Fischer, F., D. Torgerson, A. Durnová and M. Orsini (2015), 'Introduction to critical policy studies', in F. Fischer, D. Torgerson, A. Durnová and M. Orsini (eds), Handbook of Critical Policy Studies, Cheltenham, UK; Northampton, MA, USA: Edward Elgar Publishing, pp. 1-23. 
Gonzalez Hernando, M. (2019), British Think Tanks after the 2008 Global Financial Crisis, London: Palgrave Macmillan.

Goodin, R.E., M. Rein and M. Moran (2006), 'The public and its policies', in M. Moran, M. Rein and R.E. Goodin (eds), The Oxford Handbook of Public Policy, Oxford; New York: Oxford University Press, pp. 3-35.

Haas, P.M. (1992), 'Introduction: epistemic communities and international policy coordination', International Organization, 46 (1), 1-35.

Hajer, M.A. (1993), 'Discourse coalitions and the institutionalization of practice: the case of acid rain in Great Britain', in F. Fischer and J. Forester (eds), The Argumentative Turn in Policy Analysis and Planning, Durham, NC: Duke University Press, pp. 43-76.

Hall, P.A. (1993), 'Policy paradigms, social learning, and the state: the case of economic policymaking in Britain', Comparative Politics, 25 (3), 275-96.

Hart, P. 't and A. Vromen (2008), 'A new era for think tanks in public policy? International trends, Australian realities', Australian Journal of Public Administration, 67 (2), $135-48$.

Jacobs, R.N. and E.R. Townsley (2011), The Space of Opinion: Media Intellectuals and the Public Sphere, New York: Oxford University Press.

Jacques, P.J., R.E. Dunlap and M. Freeman (2008), 'The organisation of denial: conservative think tanks and environmental scepticism', Environmental Politics, 17 (3), 349-85.

Kelstrup, J.D. (2016), The Politics of Think Tanks in Europe, New York: Routledge.

Kurzman, C. and L. Owens (2002), 'The sociology of intellectuals', Annual Review of Sociology, 28 (1), 63-90.

Ladi, S. (2011), 'Think-tanks, discursive institutionalism and policy change', in G. Papanagnou (ed.), Social Science and Policy Challenges: Democracy, Values and Capacities, Paris: UNESCO, pp. 205-20.

Ladi, S., E. Lazarou and J. Hauck (2018), 'Brazilian think tanks and the rise of austerity discourse', Policy and Society, 37 (2), 222-42.

Landry, J. (2020), 'Grounding the political spectrum: how three Canadian think tanks integrate social space', Critical Policy Studies, 14 (4), 365-87.

Landry, J. (2021, forthcoming), 'What's in a think tank's mix of interventions? Plugging into politics and policymaking in Canada's knowledge regime', in D. Abelson and C. Rastrick (eds), Handbook on Policy Think Tanks, Cheltenham, UK; Northampton, MA, USA: Edward Elgar Publishing.

Lepont, U. (2016), 'The most consulted experts in the United States: the hypothesis of a peri-administration', Revue Francaise de Science Politique, 66 (6), 887-913.

Lindquist, E.A. (2004), 'Three decades of Canadian think tanks: evolving institutions, conditions and strategies', in D. Stone and A. Denham (eds), Think Tank Traditions: Policy Research and the Politics of Ideas, Manchester; New York: Manchester University Press; Palgrave, pp. 264-80.

Lövbrand, E. and J. Stripple (2015), 'Foucault and critical policy studies', in F. Fischer, D. Torgerson, A. Durnová and M. Orsini (eds), Handbook of Critical Policy Studies, Cheltenham, UK; Northampton, MA, USA: Edward Elgar Publishing, pp. 92-108.

McGann, J.G. (2002), 'Think tanks and the transnationalization of foreign policy', US Foreign Policy Agenda, 7 (3), 13-18.

McGann, J.G. (2019), 2018 Global Go To Think Tank Index Report, Philadelphia, PA: Think Tanks and Civil Societies Program. 
McKewon, E. (2012), 'Talking Points Ammo: the use of neoliberal think tank fantasy themes to delegitimise scientific knowledge of climate change in Australian newspapers', Journalism Studies, 13 (2), 277-97.

McLevey, J. (2015), 'Understanding policy research in liminal spaces: think tank responses to diverging principles of legitimacy', Social Studies of Science, 45 (2), 270-93.

Medvetz, T. (2010), “"Public policy is like having a Vaudeville act": languages of duty and difference among think tank-affiliated policy experts', Qualitative Sociology, 33 (4), 549-62.

Medvetz, T. (2012a), 'Murky power: "think tanks" as boundary organizations', in D. Courpasson, D. Golsorkhi and J.J. Sallaz (eds), Rethinking Power in Organizations, Institutions, and Markets, Bingley: Emerald Group Publishing, pp. 113-33.

Medvetz, T. (2012b), Think Tanks in America, Chicago, IL: University of Chicago Press.

Medvetz, T. (2013), 'Opening the black box of intellectual autonomy', Papers: Revista de Sociología, 98 (3), 573-9.

Medvetz, T. (2015), 'Field theory and organizational power: four modes of influence among public policy "think tanks", in M. Hilgers and E. Mangez (eds), Bourdieu's Theory of Social Fields, New York: Routledge, pp. 221-37.

Misztal, B.A. (2012), 'Public intellectuals and think tanks: a free market in ideas?', International Journal of Politics, Culture, and Society, 25 (4), 127-41.

Mouffe, C. (2005), On the Political, Abingdon: Routledge.

Nachiappan, K. (2013), 'Think tanks and the knowledge-policy nexus in China', Policy and Society, 32 (3), 255-65.

Pautz, H. (2011), 'Revisiting the think-tank phenomenon', Public Policy and Administration, 26 (4), 419-35.

Pautz, H. (2012), Think Tanks, Social Democracy and Social Policy, Basingstoke; New York: Palgrave Macmillan.

Pautz, H. (2018), 'Think tanks, Tories and the austerity discourse coalition', Policy and Society, 37 (2), 155-69.

Peetz, D. (2017), 'Why establish non-representative organizations? Rethinking the role, form and target of think tanks', in A. Salas-Porras and G. Murray (eds), Think Tanks and Global Politics: Key Spaces in the Structure of Power, New York: Palgrave Macmillan, pp. 245-63.

Peschek, J.G. (1987), Policy-Planning Organizations: Elite Agendas and America's Rightward Turn, Philadelphia, PA: Temple University Press.

Plehwe, D. (2014), 'Think tank networks and the knowledge-interest nexus: the case of climate change', Critical Policy Studies, 8 (1), 101-15.

Plehwe, D. (2015), 'The politics of policy think-tanks: organizing expertise, legitimacy and counter-expertise in policy networks', in F. Fischer, D. Torgerson, A. Durnová and M. Orsini (eds), Handbook of Critical Policy Studies, Cheltenham, UK; Northampton, MA, USA: Edward Elgar Publishing, pp. 358-79.

Plehwe, D., M. Neujeffski and W. Krämer (2018), 'Saving the dangerous idea: austerity think tank networks in the European Union', Policy and Society, 37 (2), 188-205.

Rich, A. (2004), Think Tanks, Public Policy, and the Politics of Expertise, Cambridge; New York: Cambridge University Press.

Ruser, A. (2018), Climate Politics and the Impact of Think Tanks: Scientific Expertise in Germany and the US, New York: Palgrave Macmillan.

Sabatier, P.A. (1987), 'Knowledge, policy-oriented learning, and policy change: an Advocacy Coalition Framework', Knowledge, 8 (4), 649-92. 
Salas-Porras, A. (2018), 'American think tank networks and expert debates around the Global Financial Crisis: Keynesian insurgents against austerity defenders', Policy and Society, 37 (2), 243-59.

Salas-Porras, A. and G. Murray (2017), Think Tanks and Global Politics: Key Spaces in the Structure of Power, New York: Palgrave Macmillan.

Saloma, J.S. (1984), Ominous Politics: The New Conservative Labyrinth, New York: Hill and Wang.

Sapiro, G. (2009), 'Modèles d'intervention politique des intellectuels', Actes de la recherche en sciences sociales, 2009/1-2 (176-77), 8-31.

Saretzki, T. (2015), 'Habermas, critical theory and public policy', in F. Fischer, D. Torgerson, A. Durnová, and M. Orsini (eds), Handbook of Critical Policy Studies, Cheltenham, UK; Northampton, MA, USA: Edward Elgar Publishing, pp. 67-91.

Schmidt, V.A. (2008), 'Discursive institutionalism: the explanatory power of ideas and discourse', Annual Review of Political Science, 11, 303-26.

Smith, J.A. (1991), The Idea Brokers: Think Tanks and the Rise of the New Policy Elite, New York; Toronto: The Free Press; Collier Macmillan Canada; Maxwell Macmillan International.

Stahl, J. (2016), Right Moves: The Conservative Think Tank in American Political Culture since 1945, Chapel Hill, NC: UNC Press Books.

Stampnitzky, L. (2011), 'Disciplining an unruly field: terrorism experts and theories of scientific/intellectual production', Qualitative Sociology, 34 (1), 1-19.

Stampnitzky, L. (2013), 'Experts, states, and field theory. Learning from the peculiar case of terrorism expertise', Critique Internationale, 59 (2), 89-104.

Stone, D. (1996), Capturing the Political Imagination: Think Tanks and the Policy Process, London; Portland: Frank Cass.

Stone, D. (2004), 'Transfer agents and global networks in the "transnationalization" of policy', Journal of European Public Policy, 11 (3), 545-66.

Stone, D. (2007), 'Recycling bins, garbage cans or think tanks? Three myths regarding policy analysis institutes', Public Administration, 85 (2), 259-78.

Stone, D. (2013), Knowledge Actors and Transnational Governance, London: Palgrave Macmillan.

Stone, D. and A. Denham (eds) (2004), Think Tank Traditions: Policy Research and the Politics of Ideas, Manchester; New York: Manchester University Press; Palgrave.

Stone, D., A. Denham and M. Garnett (eds) (1998), Think Tanks across Nations: A Comparative Approach, Manchester; New York: Manchester University Press; St. Martin's Press.

Torgerson, D. (2007), 'Promoting the policy orientation: Lasswell in context', in F. Fischer, G. Miller and M.S. Sidney (eds), Handbook of Public Policy Analysis: Theory, Politics, and Methods, Boca Raton: CRC/Taylor \& Francis, pp. 15-28.

Torgerson, D. (2015), 'Harold D. Lasswell and critical policy studies: the threats and temptations of power', in F. Fischer, D. Torgerson, A. Durnová and M. Orsini (eds), Handbook of Critical Policy Studies, Cheltenham, UK; Northampton, MA, USA: Edward Elgar Publishing, pp. 27-46.

Weaver, R.K. (1989), 'The changing world of think tanks', PS: Political Science and Politics, 22 (3), 563-78.

Weiss, C.H. (ed.) (1992), Organizations for Policy Analysis: Helping Government Think, Newbury Park, CA: Sage.

Zimmerman, E. and D. Stone (2018), 'ASEAN think tanks, policy change and economic cooperation: from the Asian financial crisis to the global financial crisis', Policy and Society, 37 (2), 260-75. 